\title{
LENGTH-WEIGHT AND LENGTH-LENGTH RELATIONS OF THE SEVEN ENDEMIC ALBURNUS SPECIES (ACTINOPTERYGII: CYPRINIFORMES: CYPRINIDAE) IN IRAN
}

\author{
Hamed MOUSAVI-SABET ${ }^{1 *}$, Somaye KHATAMINEJAD ${ }^{1}$, and Saber VATANDOUST ${ }^{2}$ \\ ${ }^{1}$ Department of Fisheries Sciences, Faculty of Natural Resources, University of Guilan, Sowmeh Sara, Guilan, Iran \\ ${ }^{2}$ Department of Fisheries, Islamic Azad University, Babol Branch, Mazandaran, Iran
}

\begin{abstract}
Mousavi-Sabet H., Khataminejad S., Vatandoust S. 2014. Length-weight and length-length relations of the seven endemic Alburnus species (Actinopterygii: Cypriniformes: Cyprinidae) in Iran. Acta Ichthyol. Piscat. 44 (2): 157-158.
\end{abstract}

\begin{abstract}
The length-weight (LWR) and length-length (LLR) relations were estimated for the first time for the seven endemic species of the genus Alburnus Rafinesque, 1820 inhabiting Iranian rivers namely Alburnus atropatenae Berg, 1925; Alburnus caeruleus Heckel, 1843; Alburnus chalcoides (Güldenstädt, 1772); Alburnus filippii Kessler, 1877; Alburnus hohenackeri Kessler, 1877; Alburnus mossulensis Heckel, 1843; and Alburnus zagrosensis Coad, 2009. A total of 178 specimens were caught by electrofishing during 2010-2012. The $b$ values of the LWR $\left(W=a L^{b}\right)$ ranged from 2.672 for $A$. chalcoides to 3.313 for $A$. atropatenae. The $r^{2}$ values ranged from 0.85 to 0.997 and the intercepts were between 0.0041 and 0.0190 . All LLRs were highly significant $\left(r^{2}>0.96\right)$.
\end{abstract}

Keywords: LWR, LLR, Bleak, Shemaya, Caspian Sea

Thirty-eight species are presently recognized in the European and Western Asian genus Alburnus Rafinesque, 1820 (see Kottelat and Freyhof 2007). The cyprinid genus Alburnus has seven confirmed species recorded from Iranian waters, namely Alburnus atropatenae Berg, 1925; Alburnus caeruleus Heckel, 1843; Alburnus chalcoides (Güldenstädt, 1772); Alburnus filippii Kessler, 1877; Alburnus hohenackeri Kessler, 1877; Alburnus mossulensis Heckel, 1843; and Alburnus zagrosensis Coad, 2009 (see Coad 2014).
Length-weight (LWR) and length-length relations (LLR) are widely used for fish stock assessment (Ricker 1968). The LWR is also used for estimating the average weight at a given length group and thus converting length observations into weight to provide some measure of biomass (Froese 1998, Froese et al. 2011).

In the presently reported study, the estimates of the LWR and LLR parameters for the seven endemic species of the genus Alburnus, inhabiting the rivers of Iran are presented. Among the seven studied species, only Alburnus

Table 1

Descriptive statistics and estimated parameters of the length-weight relations for the seven Alburnus species in Iran

\begin{tabular}{|c|c|c|c|c|c|c|c|c|c|c|}
\hline \multirow{2}{*}{ Species } & \multirow{2}{*}{$n$} & \multicolumn{2}{|c|}{ Total length [mm] } & \multicolumn{2}{|c|}{ Body weight $[\mathrm{g}]$} & \multicolumn{5}{|c|}{ LWR parameters } \\
\hline & & Range & Mean \pm SD & Range & Mean \pm SD & $a$ & $b$ & $r^{2}$ & $\mathrm{SE}_{b}$ & $\pm 95 \%$ CI of $b$ \\
\hline A. atropatenae & 30 & $75.45-97.44$ & $84.93 \pm 5.44$ & $3.68-8.49$ & $5.88 \pm 1.31$ & 0.0048 & 3.313 & 0.851 & 0.292 & $2.650-3.860$ \\
\hline A, caeruleus & 13 & $66.10-82.12$ & $72.60 \pm 6.49$ & $2.83-5.40$ & $3.71 \pm 1.08$ & 0.0082 & 3.072 & 0.977 & 0.290 & $2.417-3.908$ \\
\hline A. chalcoides & 30 & $124.60-184.74$ & $157.28 \pm 11.76$ & $14.88-41.70$ & $30.45 \pm 5.82$ & 0.0190 & 2.672 & 0.932 & 0.160 & $2.355-3.013$ \\
\hline A. filippii & 30 & $78.50-107.79$ & $95.80 \pm 7.48$ & $3.65-9.02$ & $6.82 \pm 1.67$ & 0.0058 & 3.115 & 0.894 & 0.259 & $2.592-3.681$ \\
\hline A. hohenackeri & 30 & $48.88-65.41$ & $56.56 \pm 5.05$ & $1.35-3.22$ & $2.14 \pm 0.56$ & 0.0158 & 2.822 & 0.943 & 0.140 & $2.487-3.064$ \\
\hline A. mossulensis & 30 & $100.94-156.88$ & $127.66 \pm 14.30$ & $8.00-28.23$ & $17.77 \pm 5.74$ & 0.0041 & 3.279 & 0.965 & 0.125 & $3.044-3.558$ \\
\hline A. zagrosensis & 15 & $53.27-129.72$ & $84.81 \pm 31.43$ & $1.40-23.04$ & $8.65 \pm 8.33$ & 0.0078 & 3.102 & 0.997 & 0.890 & $2.864-3.356$ \\
\hline
\end{tabular}

$\mathrm{SD}=$ standard deviation, $n=$ sample size, $a=$ intercept, $b=$ slope, $\mathrm{SE}_{b}=$ standard error, $r^{2}=$ the coefficient of determination, $\mathrm{CI}=$ confidence interval.

\footnotetext{
${ }^{*}$ Correspondence: Dr. Hamed Mousavi-Sabet. Department of Fisheries Sciences, Faculty of Natural Resources, University of Guilan, Sowmeh Sara, PO Box: 1144, Guilan, Iran, Phone/fax: +98 182322 3600, e-mail: (HMS) mousavi-sabet@guilan.ac.ir, (SK) khataminezhad@yahoo.com, (SV) s.vatandoust@gmail.com.
} 
Table 2

Length-length relations between total length, fork length, and standard length for the seven Alburnus species in Iran

\begin{tabular}{llll}
\hline Species & \multicolumn{1}{c}{ Equation } & $n$ & $r^{2}$ \\
\hline \multirow{4}{*}{ atropatenae } & $\mathrm{TL}=-0.074+1.0178 \mathrm{FL}$ & & 0.990 \\
& $\mathrm{FL}=-0.1142+1.0386 \mathrm{SL}$ & 30 & 0.979 \\
& $\mathrm{SL}=-0.2278+0.9205 \mathrm{TL}$ & & 0.976 \\
A. caeruleus & $\mathrm{TL}=-0.0173+1.0702 \mathrm{FL}$ & & 0.985 \\
& $\mathrm{FL}=-0.2669+1.1239 \mathrm{SL}$ & 13 & 0.993 \\
& $\mathrm{SL}=0.4011+0.8216 \mathrm{TL}$ & & 0.998 \\
A. chalcoides & $\mathrm{TL}=-0.0488+1.0021 \mathrm{FL}$ & & 0.972 \\
& $\mathrm{FL}=0.0383+0.9688 \mathrm{SL}$ & 30 & 0.979 \\
& $\mathrm{SL}=0.0775+0.9979 \mathrm{TL}$ & & 0.986 \\
A. filippii & $\mathrm{TL}=0.0057+0.9773 \mathrm{FL}$ & & 0.962 \\
& $\mathrm{FL}=-0.1134+1.0358 \mathrm{SL}$ & 30 & 0.978 \\
A. hohenackeri & $\mathrm{SL}=0.2307+0.9221 \mathrm{TL}$ & & 0.960 \\
& $\mathrm{TL}=-0.0795+1.0246 \mathrm{FL}$ & & 0.985 \\
& $\mathrm{SL}=0.0501+0.9436 \mathrm{SL}$ & 30 & 0.987 \\
A. mossulensis & $\mathrm{TL}=-0.1339+0.972 \mathrm{TL}$ & & 0.982 \\
& $\mathrm{FL}=-0.08301+1.0459 \mathrm{FL}$ & & 0.989 \\
& $\mathrm{SL}=0.2333+0.9221 \mathrm{TL}$ & & 0.997 \\
A. zagrosensis & $\mathrm{TL}=-0.0819+1.0258 \mathrm{FL}$ & & 0.989 \\
& $\mathrm{FL}=0.0823+1.0166 \mathrm{SL}$ & 15 & 0.997 \\
& $\mathrm{SL}=0.1641+0.9533 \mathrm{TL}$ & & 0.997 \\
\hline
\end{tabular}

$n=$ number of individuals, $r^{2}=$ coefficient of determination; $\mathrm{TL}=$ total length, $\mathrm{FL}=$ fork length, $\mathrm{SL}=$ standard length

mossulensis had been previously studied in terms of the length-weight relation (Mousavi-Sabet et al. 2013).

A total of 178 specimens of the seven Alburnus species (i.e. Alburnus atropatenae, Alburnus caeruleus, Alburnus chalcoides, Alburnus filippii, Alburnus hohenackeri, Alburnus mossulensis, and Alburnus zagrosensis) were collected by electrofishing from seven localities in Iran (Mahabad-Chai River 36 $48^{\prime} 56^{\prime \prime} \mathrm{N}$, $45^{\circ} 44^{\prime} 15^{\prime \prime} \mathrm{E}$; Sarabele River $33^{\circ} 41^{\prime} 34^{\prime \prime} \mathrm{N}, 46^{\circ} 42^{\prime} 56^{\prime \prime} \mathrm{E}$; Babolrud River $36^{\circ} 39^{\prime} 21^{\prime \prime} \mathrm{N}, 52^{\circ} 38^{\prime} 22^{\prime \prime} \mathrm{E}$; Baleqlu-Chai River $38^{\circ} 02^{\prime} 21^{\prime \prime} \mathrm{N}, \quad 48^{\circ} 02^{\prime} 58^{\prime \prime} \mathrm{E}$; Miriseh River $36^{\circ} 29^{\prime} 56^{\prime \prime} \mathrm{N}, 45^{\circ} 33^{\prime} 54^{\prime \prime} \mathrm{E}$; Gamasiab River $34^{\circ} 05^{\prime} 53^{\prime \prime} \mathrm{N}$, $48^{\circ} 25^{\prime} 21^{\prime \prime} \mathrm{E}$; and the Gandoman Wetland $31^{\circ} 50^{\prime} 09^{\prime \prime} \mathrm{N}$, $51^{\circ} 06^{\prime} 03^{\prime \prime} \mathrm{E}$; respectively) during 2010-2012. Specimens were preserved in $10 \%$ formaldehyde and their total length (TL), fork length (FL), and standard length (SL) were measured to the nearest $0.01 \mathrm{~mm}$, and body weighed $(W)$ to the nearest $0.01 \mathrm{~g}$.

The parameters of the LWR $W=a L^{b}$ (Le Cren 1951), were calculated by the least squares method using the logarithmic form: $\log W=\log a+b \log$ TL.

Moreover, TL vs. FL, FL vs. SL, and SL vs. TL relations (LLR) were estimated with linear regression.

Descriptive statistics and estimated parameters of the LWR are given in Table 1 and the LLR in Table 2. All $r^{2}$ values were highly significant $\left(r^{2}>0.96\right.$ for LLR, $r^{2}>0.85$ for LWR).

\section{ACKNOWLEDGEMENTS}

The authors are thankful to Mr. Hamid Reza Bagherpour and Mr. Arash Jouladeh for their help in collecting the specimens, Dr. Soheil Eagderi and Dr. Hamid Reza Esmaeili for providing some of the studied materials, and Ms. Zeynab Moradkhani for improving the English in the manuscript.

\section{REFERENCES}

Coad B.W. 2014. Freshwater fishes of Iran. http://www.briancoad.com [Accessed: February 2014]

Froese R. 1998. Length-weight relationship for 18 less-studied fish species. Journal of Applied Ichthyology 14 (1-2): 117-118. DOI: 10.1111/j.1439-0426.1998.tb00626.x

Froese R., Tsikliras A.C., Stergiou K.I. 2011. Editorial note on weight-length relations of fishes. Acta Ichthyologica et Piscatoria 41 (4): 261-263. DOI: 10.3750/AIP2011.41.4.01

Kottelat M., Freyhof J. 2007. Handbook of European freshwater fishes. Kottelat and Freyhof, Cornol, Switzerland, Berlin, Germany.

Le Cren E.D. 1951. The length-weight relationship and seasonal cycle in gonad weight and condition in the perch (Perca fluviatilis). Journal of Animal Ecology 20 (2): 201-219. DOI: $10.2307 / 1540$

Mousavi-Sabet H., Abdollahpour S., Salehi-Farsani A., Vatandoust S., Langroudi H.F., Jamalzade H.R., Nasrollahzadeh A. 2013. Length-weight and length-length relationships and condition factor of Alburnus mossulensis from the Persian Gulf basin. AACL Bioflux 6 (4): 297-302.

Ricker W.E. (ed.) 1968. Methods for assessment of fish production in freshwaters. IBP Handbook No. 3. Blackwell Scientific Publications, Oxford and Edinburgh, UK.

Received: 3 May 2013

Accepted: 6 March 2014

Published electronically: 30 June 2014 